VIII-1 | 2016

Dewey's Democracy and Education as a Source of and a Resource for European Educational Theory and Practice

\title{
Educational Occupations and Classroom Technology
}

Lessons from Democracy and Education

Larry A. Hickman

\section{OpenEdition}

Journals

Electronic version

URL: http://journals.openedition.org/ejpap/446

DOI: $10.4000 /$ ejpap.446

ISSN: 2036-4091

\section{Publisher}

Associazione Pragma

Electronic reference

Larry A. Hickman, «Educational Occupations and Classroom Technology », European Journal of Pragmatism and American Philosophy [Online], VIII-1 | 2016, Online since 20 July 2016, connection on 19 April 2019. URL : http://journals.openedition.org/ejpap/446 ; DOI : 10.4000/ejpap.446

This text was automatically generated on 19 April 2019

\section{(c) (i) (9)}

Author retains copyright and grants the European Journal of Pragmatism and American Philosophy right of first publication with the work simultaneously licensed under a Creative Commons AttributionNonCommercial-NoDerivatives 4.0 International License. 


\title{
Educational Occupations and Classroom Technology
}

Lessons from Democracy and Education

\author{
Larry A. Hickman
}

1 In 1896 John Dewey established a laboratory school at the University of Chicago. If departments of physics and chemistry had laboratories, then why should not a department of pedagogy have one as well? Dewey's school was designed to express his commitment to evolutionary naturalism, that is, his view that since humans have evolved along with the rest of nature they should therefore be studied just as other animals are studied. ${ }^{1}$

Breaking with a long tradition of $a$ priori ${ }^{2}$ approaches to philosophy and pedagogy, he treated logic and epistemology as natural sciences. As he would write three years later in The School and Society, schools should be designed to provide an environment of embryonic community life, active with types of occupations which reflect the life of the larger society, and permeated throughout with the spirit of art, history, and science. When the school introduces and trains each child of society into membership within such a little community, saturating him with the spirit of service, and providing him with the instruments of effective self-direction, we shall have the deepest and best guarantee of a larger society which is worthy, lovely, and harmonious. (MW 1: 19-20) ${ }^{3}$

Dewey thought that individual lives should be informed with the life of nature and of society. "When nature and society can live in the schoolroom," he wrote, "when the forms and tools of learning are subordinated to the substance of experience, then shall there be an opportunity for this identification, and culture shall be the democratic password" (MW 1: 39). His students practiced this unification of nature and society by means of what he called "occupations." There was, for example, work with wood. There was cooking, sewing, and work with textiles.

In his 1916 masterwork Democracy and Education, Dewey is clear that emphasis on "occupations" was a response to the "memorize and drill" pedagogies of the 19th century 
- those antique educational ideas that have, sadly, enjoyed a revival in the late 20th and early 21st centuries in the form of "teaching to the test" pedagogies associated with No Child Left Behind and Common Core initiatives in the United States. Dewey was clear enough about his dislike of such practices: "Education is not an affair of 'telling' and being told," he wrote, "but an active and constructive process" (MW 9: 43).

Although these occupations - work with wood, cooking, sewing, work with textiles, and so on - are still important, they no longer hold the central place they did when Dewey's school was new. They have been for the most part replaced by other classroom occupations such as video production, use of social media, techniques of hunting and gathering information on the Internet, writing computer programs, spreadsheet and database management, web page design, robotics, and 3-D printing.

As different as these 21st century occupations may initially appear from those of Dewey's school, they in fact share common contexts, elements, and aims that Dewey spelled out in his works on education, especially in Democracy and Education. Contexts include the home, the school, the community, industry, the internet, and the wider world. Elements include raw materials, stock parts, tools - both existing and yet to be invented and developed as a part of the learning process - and finished products. Aims include socialization and experimentation, communication and negotiation as a part of conjoint activities, building on the success of competed educational projects, and acquiring skills that support lifelong learning.

7 1. Educational occupations flow from the native tendencies of children. Dewey's view of the individual was radical, and his view of the social was equally radical. His radical social psychology rejected the notion that humans are essentially passive and need to be prodded into action. As a Darwinian naturalist he thought that humans have evolved along with the rest of nature and that in order to flourish they must continually adjust to changing environmental circumstances by forming and reforming habits of action, and by reconstructing received customs and traditions as the need arises. Some situations demand that environing conditions should be altered. Others demand accommodation to relatively external conditions on the part of the individual or group. An essential part of educational practice is providing educational occupations that allow learners to balance these two demands as a part of learning to manage change.

He thought that neonates are individuals only in the most attenuated of senses. One of the central aims of education is the type of growth that allows children to become individuals in a more meaningful sense of the word - individuating themselves as they explore their talents and interests and as they find places for themselves within the natural and social environments. It is thus the responsibility of those who are a part of their social environments to assure that impediments to learning are removed and that the way is cleared for the continual reconstruction and renewal of society.

Dewey recognized that children are energetic by nature and that they enjoy experimenting with materials and making things. Educational occupations thus flow naturally from "native tendencies to explore, to manipulate tools and materials, to construct, to give expression to joyous emotion" (MW 9: 202). Dewey consequently restructured classroom design in order to free up spaces for motor activities and social interaction. He rejected theories of a fixed human nature, which he thought were blind to the wonderful plasticity of the human organism. His pedagogy was based on the idea that humans have native impulses, many of which are in conflict with others. The task of education is to generate the tools by means of which students can learn to organize and 
manage their impulses in productive ways - ways that facilitate the formation of good habits. Beyond that, he understood "character" as a way of talking about particular constellations of habits that influence not only present action, but also the formation of future habits. Proper deployment of educational occupations is thus essential to organizing native impulses and forming the habits that contribute to the formation of good character.

10 2. Educational occupations tend to balance theory and practice. The "fundamental point in the psychology of an occupation," Dewey wrote in The School and Society, "is that it maintains a balance between the intellectual and the practical phases of experience" (MW 1: 92). The traditional theory/practice split was one among the many dualisms such as mind/body, inner/outer, and means/ends that Dewey attacked as militating against sound pedagogy. When education slips into what he termed "academic and aloof knowledge," on one hand, or "a hard, narrow, and merely 'practical' practice" on the other, then it fails (MW 9: 144). In Democracy and Education Dewey treats the relation of theory to practice as the relation of reason to acting (MW 9: 340). He treats theory and practice as phases of educational occupations, that is, as complementary aspects of learning experiences (MW 9: 144).

11 Dewey's remarks on the relation between theory and practice is perhaps best understood in the context of his remarks about the relation of means to ends. Theory is means and it is also end. It is means in the sense that theoretical constructs are tools that are utilized in educational occupations to support deliberation about and assessment of the consequences of proposed actions. Theory is also end in the sense that theories are constructed objects, to be constructed, that is, in ways that reflect the needs of the educational context. Practice is also means as well as end. Improved practice serves as end in the sense of the goal, or what Dewey calls an end-in view, of an educational occupation. Practice also serves as means for moving activity, including thought, forward, for reviewing and correcting errors - and building on successes.

12 3. Educational occupations serve as means to the end of socialization. It is essential, therefore that they involve joint activities. Here, again, is Dewey in Democracy and Education:

We may secure motor activity and sensory excitation by keeping an individual by himself, but we cannot thereby get him to understand the meaning which things have in the life of which he is a part [...]. Only by engaging in a joint activity, where one person's use of material and tools is consciously referred to the use other persons are making of their capacities and appliances, is a social direction of disposition attained. (MW 9: 44)

13 It is a commonplace that we generally read silently and alone, and that reading provides access to a wider world, to citizenship in what some have called "the republic of letters." But in Dewey's enriched pedagogy learning does not flower unless nourished by the sun and water and soil of personal interaction. For learners, one of the great lessons of working together on joint projects is that different backgrounds, talents, interests, and angles of vision usually make for better and more interesting ideas and outcomes. This, Dewey said, is not preparation for democracy; it is small scale democracy in action. So Dewey thought that schools were laboratories of democracy: joint activities yield rich lessons in cooperation, respect for the opinions of others, acceptance of diversity of many types, acknowledgment of the need for negotiation and compromise, and many other traits that are necessary to the functioning of a democratic society. Dewey went so far as to suggest that democracy is less a form of government (since democratic government 
can take many forms) than it is a way of living together. Activities associated with joint projects provide the conditions that are required for the seedlings of democracy to grow.

4. Educational occupations establish a continuity of the tools of school with the tools of home and industry. Educators trained in Dewey's methods will recognize the fact that for those of school age the Internet is not merely a means of getting information: it is a means of communication. Educational occupations can be designed to build on the fact, for example, that YouTube users older than 13 can create accounts which allow them to upload videos and comment on the videos of others. ${ }^{4}$

Noel Murray, writing in the New York Times, notes that YouTube has built production facilities around the world

to provide their best known creators access to soundstages and equipment. Yet the success of many of the site's most beloved content producers may reflect their videos' homemade charm, not their professional polish. (Murray 2015: F4)

Murray concludes that children have come to see online videos as another form of communication, akin to the conversations they have in the comments section of web sites. It does not take much of an imaginative leap to see the possibilities for educational occupations in this situation. Production facilities in schools can allow students - working together - to produce classroom projects and share them with students at other schools, thus expanding the scope of one of the pillars of Dewey's pedagogy: peer-based learning. This transition from watching passively to actively creating is precisely what Dewey had in mind.

17 5. Educational occupations develop the skills necessary for development of more advanced skills. Put another way, well designed educational occupations encourage further educational activities that are built on successful outcomes. Beyond the occupations already mentioned, Dewey includes "outdoor excursions, gardening, cooking, sewing, printing, book-binding, weaving, painting, drawing, singing, dramatization, story-telling, reading and writing." These are "active pursuits with social aims (not as mere exercises for acquiring skill for future use) [...] and designate some of the modes of occupation" (MW 9: 204).

6. Educational occupations develop the tools and techniques of self direction. Collaborative work in the classroom situations not only socializes; it also provides tools by means of which learners can begin to craft their own futures based on increasing awareness of their talents and abilities, their interests, and their capacity for bringing energy and discipline to future learning projects.

7. Educational occupations integrate play and work. Dewey claims that

the defining characteristic of play is not amusement nor aimlessness. It is the fact that the aim is thought of as more activity in the same line, without defining continuity of action in reference to results produced. (MW 9:213-4)

Educational occupations are effective when they involve "knowledge-getting" that is "an outgrowth of activities having their own end, instead of a school task" (MW 9: 203).

8. Educational occupations involve tool use. Central to Dewey's treatment of technology was his claim that the difference between concrete and abstract tools, between those that are tangible and those that are intangible, is merely functional within a broader context of technology, that is, inquiry into the nature and use of tools and techniques. Technology is thus the 'logos' of techne. It is not necessary that learners know the properties of tools and objects before they can be intelligently used (MW 9: 297). Learners 
learn to use tools by using them, not being told about their use. Perhaps even more importantly the use of tools should emerge from the educational occupation and not be imposed on it. Attempts to impose irrelevant tools on learning situations can lead to resistance and reluctance to explore new technical possibilities.

A passage from Nobel physicist Richard Feynman's (1999: 178) book The Pleasure of Finding Things Out illustrates this insight from Democracy and Education. Feynman invites us to consider a first grade science book, a science book for six-year olds. He sees three pictures. The first is a picture of a wind-up toy dog. The second is a picture of a real dog. The third is a picture of a motor bike. Under each picture there is a caption: "What makes it move?" The teacher's manual provides the answer. The teacher is supposed to tell the children that what makes each of these things move is energy.

Feynman is not impressed. He doesn't think that this is the way to teach science to sixyear olds (or anyone else, for that matter). Neither did Dewey, who reminded us that "education is not an affair of 'telling' and being told, but an active and constructive process" (MW 9: 43). Dewey thought that energy is a concept - an abstract tool that is used to perform functions such as getting additional data about some problem that we want to solve. It is like a key that opens the door to new ideas and new data. But is certainly not a definition that students need to memorize so that the teacher can tell them that each of the three pictures fit the definition. Dewey thought that that is an excellent way to hamper the excitement of learning about science.

Feynman's alternative approach was similar to Dewey's. Why does the toy dog move? It moves because the child winds up the spring, which begins to unwind when the crank is released. The child discovers that as the spring unwinds it runs the gears, which make the toy dog's legs move. Feynman and Dewey are clear: successful educational occupations require active use of tools: it is better for the child to take the toy dog apart to see how it works than to memorize the definition of "energy." Taking the toy dog apart is a good way to teach and learn science. Getting children to memorize the definition of 'energy' is not.

Beyond this simple example, it is important to note that tools - physical as well as conceptual - allow development of indeterminate or problematic situations into those that are well ordered and satisfactory in ways that are not definable a priori. ${ }^{5}$ Dewey's remarks on concept formation are appropriate to this topic. Children, for example, form concepts as tools of inquiry first by identifying something of interest, say a dog. Then, with the help of a teacher or other adult, they supplement that incipient and tenuous concept by means of trials, errors, and corrections that determine other instances of its (canine) type, for example, by being corrected when they mistakenly identify a horse as a 'big dog.' Success comes when the child is able to locate what has been refined and reconstructed within a broader context in ways that resolve the tension in the original situation, for example, by developing the ability to distinguish various breeds of dogs. Dewey's analysis of concept formation was, of course, borrowed from the sciences. Like other tools, he suggested, "the significance of atoms, molecules, and chemical formulae [...] can be learned only by use" (MW 9: 229).

26 9. Educational occupations encourage the development of abstraction and scientific thinking. They encourage the development of tools that are flexible and that may not have an immediately obvious use.

The man of science in developing his abstractions is like a manufacturer of tools who does not know who will use them nor when. But intellectual tools are 
indefinitely more flexible in their range of adaptation than other mechanical tools.

(MW 9: 233)

He thought the relation between abstraction and generalization of paramount importance. Generalization, he wrote, is "the functioning of an abstraction in its application to a new concrete experience - its extension to clarify and direct new situations" (MW 9: 235). Dewey tells us that scientific abstraction and generalization are the keys to objectivity, that is, of "emancipation from the conditions and episodes of concrete experiences" in order to foster the "wide and free range of fruitful novel applications in practice."

The success of learners' involvement with educational occupations depends on adequate preparation by a number of parties. ${ }^{6}$ In what may have been a rebuke to some of his selfstyled followers whose pedagogy favored lack of structure, Dewey reminded us that

[i]ntentional education signifies [...] a specially selected environment, the selection being made on the basis of materials and methods specifically promoting growth in the desired direction. (MW 9: 43)

Moreover, control of educational occupations

is not the same thing as physical compulsion; it consists in centering the impulses acting at any one time upon some specific end and in introducing an order of continuity into the sequence of acts [...]. The basic control resides in the nature of the situations in which the young take part [...]. To achieve [...] [this] internal control through identity of interest and understanding is the business of education. While books and conversation can do much, these agencies are usually relied upon too exclusively. Schools require for their full efficiency more opportunity for conjoint activities in which those instructed take part, so that they may acquire a social sense of their own powers and of the materials and appliances used. (MW 9: $44-5)^{7}$

Dewey thought that every school classroom should be a laboratory. This view is apparently shared by the Innovative Technology for an Engaging Classroom, henceforth iTEC. ${ }^{8}$

Over the course of the project, educational tools and resources were piloted in over 2,500 classrooms across 20 European countries, with the goal of providing a sustainable model for fundamentally redesigning teaching and learning. The project involved 26 project partners, including 14 Ministries of Education, and funding of $€ 9.45$ million from the European Commission’s FP7 programme. The project ended in August 2014.

31 The project of European Schoolnet, henceforth EUN, 9 "provides both Ministries and schools with: information and services relating to the innovative use of educational technology; outreach campaigns on specific educational topics such as maths, science and technology; and research activities" [eun.org/about], which has developed a "Future Classroom Lab." "Since the opening of the Future Classroom Lab in January 2012, European Schoolnet and its 30 supporting Ministries of Education have worked closely with a growing number of ICT [Information and Communication Technology] providers to ensure an independently-funded and sustainable platform. Policy-makers, industry partners, teachers and other education stakeholders regularly come together in face-toface training workshops and strategic seminars to develop visions for the school of the future and strategies on how to realise these." With toolsets for constructing educational occupations that Dewey would, I suggest, have found congenial. 

of life, Dewey continually emphasized the importance of communication among interested and affected parties, or what we today call stakeholders, as essential to the reconstruction and renewal of received customs and practices. He was particularly eager to see that schools take their place as active participants in the life of the wider community, and that the wider community enter into the life of the schools. called "dramatic rehearsals," as a part of problem solving. Although I will have more to say about this later, it is important to note that Toolset 1 offers guidelines for identifying trends in emerging technologies and trends in teaching and learning (such as the inverted or "flipped" classroom), using questionnaires that invite the use of dramatic rehearsals: What technologies will have an impact on teaching and learning in the next five years? What are the challenges that will have an impact on teachers in the next five years? What are the challenges that will have an impact on students in the next five years? Trends are then ranked as a part of small group discussions.

cassrooms are to be laboratories that support educational occupations, as Dewey argued they should be, then teachers need to be aware not only of trends and possibilities, but of existing conditions that influence the quality of teaching and learning.

Toolset 2 provides an interactive tool for assessing available digital learning resources and comparing those results to a benchmark. Supporting materials include videos that provide examples of five levels of "future classroom maturity." Because the first level registers the use of what are for the most part traditional learning tools and methods, and because the fifth level registers a connected classroom in which learners are more or less self-guided with respect to their learning skills and teachers are empowered to become innovative, these five levels of "classroom maturity" are worth describing in some detail.

1. The lowest level is "Exchange." At this level there is little support or training for teachers in areas of digital learning. Use of digital tools is usually confined to individual teachers, so that teaching and learning are isolated. Digital tools are used infrequently and then only primarily to support traditional methods. Put in terms of Dewey's discussion of educational occupations, there is at this stage a lack of continuity between tools of school with the tools of home and industry. Learners who have a rich digital environment at home will tend to find the learning environment of the school isolated and boring.

38 2. At the next level, "Enrich," the teacher decides what technology the learners use, but may lack full understanding of its benefits. Training and support are primarily technical 
rather than pedagogical. Teachers are "enriched" by use of digital tools, but tend generally to be uncomfortable with their use. The learner becomes the user of digital tools, but at the direction of the teacher. There is little personalization of learner's activities. In terms of Dewey's treatment of educational occupations, there is at this stage still a measure of alienation of both teacher and learner from digital tools that could enrich the learning experience. Tools tend to be imposed on the learning experience rather than being chosen as relevant to and facilitating the learning experience.

3. At the level of "Enhance" there is more active experimentation by teachers with digital tools. Teachers are supported with ICT training. Learners are encouraged to develop more personalized, individuated learning objectives tied to objectives outlined in a "21 Century Skills" document. ${ }^{11}$ Skills listed include: "Critical thinking, problem solving, reasoning, analysis, interpretation, synthesizing information; Research skills and practices, interrogative questioning; Creativity, artistry, curiosity, imagination, innovation, personal expression; Perseverance, self-direction, planning, self discipline, adaptability, initiative; Oral and written communication, public speaking and presenting, listening; Leadership, teamwork, collaboration, cooperation, facility in using virtual workspaces; ITC literacy, media and internet literacy, data interpretation and analysis, computer programming; Civic, ethical, and social justice literacy; Economic and financial literacy, entrepreneurialism; Global awareness, multicultural literacy, humanitarianism; Scientific literacy and reasoning, the scientific method; Environmental and conservation literacy, ecosystems understanding; Health and wellness literacy, including nutrition, diet, exercise, and public health and safety." Teachers become more comfortable with digital tools and learners begin to use technology to support creativity, collaboration and communication. Individualized assessment tools improve the performance of learners. In terms of Dewey's discussion of educational occupations, it is at this stage that educational occupations begin to serve as means of improved socialization. Teacher/learner collaborations begin, and learning scenarios become more fluid and flexible.

4. At the level of "Extend," learners gain greater control of what, how, and when they learn. There is increased initiative and connectedness on the part of teachers, who are encouraged to develop innovative approaches to learning and to share them with other teachers in their own school as well as those in other schools. Teachers are digitally competent and engage learners in ways that overcomes the gap between formal and informal learning. There is an increased emphasis on collaboration. Traditional subject boundaries are lowered as learner progress becomes more individualized. In this stage and the next one the core ideas of Dewey's pedagogy are ideally expressed. The environment is structured but experimental, educational occupations reflect the interests of teachers and learners, levels of collaboration are high, peer learning is emphasized, and the classroom is opened to the wider world.

41 5. At the level of "Empower," teachers and learners are empowered to experiment with and adapt new approaches and tools. The school is committed to innovation and teachers are sufficiently trained in the use of future classroom tools. Learning objectives are continually reviewed and there is a balance between assessment of formal skills, on one side, and developing skills that are less easily assessed, on the other. Learners become more self-directed and teachers become collaborative designers of innovative learning activities. In the language of Democracy and Education, at this ultimate stage educational occupations develop the skills necessary for development of more advanced skills. They encourage further educational activities built on successful outcomes. 

groups work collaboratively to create new scenarios or build on existing ones that are at least one level higher on the "classroom maturity model" than previous scenarios. Attention is directed to concerns such as: learners' skills to be developed; building future classroom maturity; specifying learning objectives and means of assessment; and writing or adapting the scenario narrative so as to take into consideration the learners' role, the teachers' role, the capacity of the school to support classroom innovation, and availability of required tools and resources.

Toolset 4. Whereas future classroom scenarios establish a vision of what a school thinks possible and desirable for the future of teaching and learning, in order to realize these visions teachers work together to create a set of learning activities such as creating a video or collecting data or images from outside the school. It is important to note that they involve collaborative design, that they are not tied to a particular subject area, that they are not lesson plans per se but activities that both seasoned and novice teachers can use to prepare their own lesson plans, and that they are open to revision. Finally, there are "learning stories," which are narratives that give teachers a sense of how learning activities could be used in their own classrooms. Teachers can access a Widget Store, which is an online tool for storing small reusable learning tools that can be used within their own Learning Platform.

Toolset 5 provides suggestions for review and assessment of classroom projects. In this toolset teachers also have access to "share your story" videos and other materials that allow them to see what other teachers have done.

\section{米}

In the preceding paragraphs I have suggested that the ideals and proposals set out in documentation supplied by the "Future Classroom Toolkit" project of European Schoolnet are consistent with the main themes of Democracy and Education. Now I want to discuss another initiative of the EUN that is imbedded within the larger educational project that I believe Dewey would also have found congenial: the inverted or "flipped classroom." Although the literature of the EUN and its various projects does not appear to emphasize the inverted classroom as a major feature of its initiatives, this may be because the concept has been so successfully integrated into the projects as a whole.

Kerry Shoebridge, a physical education teacher in the U.K. reports that she created a video for the learners that introduced a new topic. They then used an online discussion board to comment on it and came to the classroom "really engaged, really wanting to know what the unit was going to be about, and what they were going to learn." 12 According to the report, "Kerry's flipped classroom was a big success, with $95 \%$ of her pupils passing. According to the students themselves, it was not just using technology that was important, but the fact that ICT supported independent learning by enabling students to take notes in whatever way they liked, and facilitated them developing their own learning styles." 13

It may be helpful here, therefore, to say something more about the flipped classroom and how it relates to Dewey's proposals in Democracy and Education. In 2012 Mary Beth Hertz, an Arts/Tech teacher in Pennsylvania reviewed the flipped classroom for Edutopia, a nonpartisan foundation dedicated to the improvement of K-12 education. ${ }^{14}$ She emphasized 
that the flipped classroom is not a synonym for online videos. In words that echo Dewey's remarks in Democracy and Education, she quoted flipped-classroom pioneer Jonathan Bergmann: "It is the interaction and the meaningful learning activities that occur during the face-to face time that is the most importance." Hertz is wary of "off the shelf" flippedclassroom products marketed by for-profit educational suppliers, and she is also critical of Kahn Academy's use of the technique in ways that neglect its multidimensional capabilities. She is also convinced that not everyone learns best through a screen. In general, however, she sees the flipped classroom as offering teachers and learners a wide assortment of techniques that promote individualized learning, that allow students to catch up when they miss classes, and that tend to provoke enthusiastic responses from learners.

Hertz also points out that the idea is hardly new.

Listening to Aaron Sams talk [youtube.com/watch?v=2H4RkudFzlc] about his experience with the flipped-classroom model, one can't help but imagine that what he is describing doesn't require video at all. What he describes is, in essence, what John Dewey described at the turn of the 20th century: learning that is centered around the student, not the teacher; learning that allows students to show their mastery of content the way they prefer. These are not new concepts. ${ }^{15}$

Flipped classroom researchers Jacob Lowell Bishop and Matthew A. Verleger, focusing on learning in higher education, come to a different conclusion regarding the use of video. They define the flipped classroom more narrowly than does Hertz, as a "new pedagogical method, which employs asynchronous video lectures and practice problems as homework, and active, group-based problem solving activities in the classroom. It represents a unique combination of learning theories once thought to be incompatibleactive, problem-based learning activities founded upon a constructivist ideology and instructional lectures derived from direct instruction methods founded upon behaviorist principles" (Bishop \& Verleger 2013: 1). They cite research that shows that college students don't generally complete reading assignments and prefer "live in-person lectures to video lectures," but also like "interactive class time more than in-person lectures" (Bishop \& Verleger 2013: 9).

50 A study published by the Flipped Learning Network (Hamdan et al. 2013) also reinforces central concepts of the pedagogy of Democracy and Education, supported with new digital tools. "Teachers record and narrate screencasts of work they do on their computer desktops, create videos of themselves teaching, or curate video lessons from internet sites such as TED-Ed and Khan Academy" (Hamdan et al. 2013: 4). What they describe as the four pillars of flipped learning fit nicely with the pillars of Dewey's pedagogy that I discussed earlier. First, flipped learning requires flexible environments in which students choose when and where they learn. Consequently, educators need to be flexible in terms of how students are assessed. Second, flipped learning requires a shift in the learning culture away from the teacher-centered classroom to a student centered approach. Third, flipped learning requires intentional content. Teachers evaluate what content they need to teach directly and what materials learners need to explore on their own outside the group learning experience. Teachers can call on a variety of techniques, including peer instruction, problem-based learning, Socratic methods, and so on. Fourth, flipped learning requires professional educators. Learning is enabled by digital tools, rather than being driven by them. Flipped learning involves active learning, peer instruction, priming (preparing learners with direct instruction outside the classroom), pre-training (in order 
to reduce the cognitive load on learners), and provision for diverse learning opportunities.

\section{Conclusion}

51 Returning to the iTEC project, it is possible to say by way of summary that it appears to promote the core concepts of the educational occupations discussed in Democracy and Education and elsewhere in Dewey's work. These include recognition of a broad range of stakeholder interests, provision of time and space for teachers to step back and consider new ways of instruction, promotion of project-based learning, promotion of peer-based learning, treatment of teachers as learners who collaborate with their students via social media and digital tools such as Dropbox, respect for different cognitive styles, encouragement of flexible methods of assessment, commitment to a pedagogy that is enabled but not driven by digital tools, empowerment of teachers, appropriate use of quantitative tools, scalability, engagement of learners' motor responses, development of learners' sense of ends/means relationships, recognition of classroom as workshops of democracy, enhancement of student motivation, and sharing of best practices among teachers.

There is of course much more to the European Schoolnet project than the iTEC component. I have not considered, for example, the "1 to 1 Pedagogy for Schools Project," which explores the use of low cost computer devices, ranging from mobiles and handhelds to laptops or netbooks, in educational contexts. This essay has merely attempted to examine EUN's iTEC proposals for the use of educational technology in the context of Dewey's masterwork, Democracy and Education.

\section{BIBLIOGRAPHY}

BISHOP J., \& M. A. VERLEGER, (2013), “The Flipped Classroom: A Survey of the Research”, paper presented at the 2013 ASEE Annual Conference, Atlanta, GA, available at [peer.asee.org/22585]. CUNNINGHAM C. A., (2009), “Transforming Schooling through Technology: Twenty-First-Century Approaches to Participatory Learning," Education and Culture, 25, 2, 46-61.

DEWEY J. (1969-1991), The Collected Works (1882-1953), edited by Boydston J. A., 37 vols., Carbondale and Edwardsville, IL, Southern Illinois University Press.

FEYNMAN R., (1999), The Pleasure of Finding Things Out, Cambridge, Perseus Books.

HAMDAN N., MCKNIGHT P., MCKNIGHT K., \& K. M. ARFSTROM, (2013), “A Review of Flipped Learning,” Flipped Learning Network, available at [flippedlearning.org/review].

KOzOL J., (1991), Savage Inequalities, New York, Crown Publishers.

MURRAY N., (2015), “The Viewer as Creator," New York Times, October 5, F4. 
NOGUERA P, \& J. YONEMURA WING, (2006), Unfinished Business: Closing the Racial Achievement Gap in Our Schools, San Francisco, Jossey-Bass.

WADDINGTON D. I., (2015), "Dewey and Video Games: From Education through Occupations to Education through Simulations," Educational Theory, 65, 1, 1-20.

WAKS L. J., (2001), “Computer Mediated Experience and Education,” Educational Theory, 51, 4, 415-32.

WAKS L. J., (2014), Education 2.0. The Learningweb Revolution and the Transformation of the School, Boulder, Co, Paradigm Publishers.

\section{NOTES}

1. For a helpful account of the history of Deweyan participatory learning, see Cunningham 2009. Cunningham addresses some of the same issues that motivate this essay. "Students can participate in collaborative activities that reflect current knowledge and contemporary situations and yet are sufficiently scaffolded to allow for meaningful and safe participation by a wide variety of learners in a limited amount of time. [...] Deweyan educators should acquaint themselves with these possibilities, if only to see what might be learned from them about the prospects of participatory learning for the twenty-first century" (Ibid.: 51).

2. See Waks 2001. Waks discusses updated applications of Dewey's notion that the school should be connected with out-of-school life, including the lives of business and industry. Progressive teaching methods, he argues, should now include cyber-simulations of natural and social processes. "[G]ames add something special: their alterations of skill and luck, necessity and chance, competition and cooperation, tension and release, make them excellent general models of real life" (Ibid.: 416).

3. References to John Dewey's published works are to the critical edition, The Collected Works of John Dewey, 1882-1953, edited by Boydston J.A., Carbondale and Edwardsville, Southern Illinois University Press, 1967-1991, and published in three series as The Early Works 1882-1899 [EW], The Middle Works 1899-1924 [MW], and The Later Works 1925-1953 [LW].

4. This type of interaction/production in the classroom is an important feature of the European Schoolnet, which I will discuss later.

5. For more on this see Waks 2014. Waks provides an extended discussion of the old "factory" paradigm of education and the new "networked learning" paradigm. of particular relevance to educators is his Ch. 15: "What Needs To Be Done?"

6. There is a vast literature dedicated to institutional failures to provide adequate preparation for support of educational occupations. In the United States, for example, many educators are highly critical of the lack of equalized funding across public school systems (see Kozol 1991). Racial and economic inequalities also come into play (see Noguera \& Yonemura Wing 2006.) In the view of many educators, top-down government-imposed mandates for standardized, highstakes testing (No Child Left Behind, Race to the Top, the Common Core) also tend to interfere with providing adequate preparation for the success of educational occupations.

7. For more on this see Waddington 2015.

8. From the European Schoolnet Website: "In iTEC (Innovative Technologies for Engaging Classrooms, 2010-2014), European Schoolnet worked with education ministries, technology providers and research organizations to transform the way that technology is used in schools."

9. Here is the "About" statement of the European Schoolnet: "European Schoolnet is the network of 31 European Ministries of Education, based in Brussels. As a not-for-profit organization, we aim to bring innovation in teaching and learning to our key stakeholders: Ministries of 
Education, schools, teachers, researchers, and industry partners. Since its founding in 1997, European Schoolnet has used its links with education ministries to help schools make effective use of educational technologies, equipping both teachers and pupils with the skills to achieve in the knowledge society."

10. From the European Schoolnet Website: "Created by European Schoolnet, the Future Classroom Lab (FCL) is an inspirational learning environment in Brussels, challenging visitors to rethink the role of pedagogy, technology and design in their classrooms. Through six learning zones, visitors can explore the essential elements in delivering 21st century learning: students' and teachers' skills and roles, learning styles, learning environment design, current and emerging technology, and societal trends affecting education."

11. See [edglossary.org/21st-century-skills/] for an article on 21st century skills posted as a part of the Glossary of Education Reform, sponsored by the Great Schools Partnership. The essay contains the following disclaimer: "While the specific skills deemed to be '21st century skills' may be defined, categorized, and determined differently from person to person, place to place, or school to school, the term does reflect a general - if somewhat loose and shifting - consensus. The following list provides a brief illustrative overview of the knowledge, skills, work habits, and character traits commonly associated with 21 st century skills."

12. Designing the Future Classroom, Issue 2, August 2014, p. 2. Publication of the European Schoolnet avilable at [fcl.eun.org/documents/10180/16159/FCL-magazine-No-2-2014EN.pdf/485d930e-1b1d-40c1-86a5-2a6567857a10].

13. Designing the Future Classroom, Issue 2, August 2014, p. 2. Publication of the European Schoolnet.

14. Mary Beth Hertz, "The Flipped Classroom: Pro and Con|Edutopia." [edutopia.org/blog/ flipped-classroom-pro-and-con-mary-beth-hertz].

15. Hertz: 3.

\section{ABSTRACTS}

Despite the fact that John Dewey had a great deal to say about education and technology, many of his insights have yet to be understood or appropriated. A close reading of Democracy and Education offers support for the view that Dewey was prescient in proposing a pedagogy that was friendly to current initiatives in innovative classroom technology including inverted or "flipped" classroom projects in the United States and elsewhere and the Future Classroom Lab project of the European Schoolnet. In both of these initiatives application of tools and techniques grow out of educational occupations guided by teachers rather than being imposed on learning situations a priori. Both initiatives honor the pillars of Dewey's educational philosophy as presented in his 1916 Democracy and Education and elsewhere in his work: problem-or theme-based learning, peerbased learning, learning that is open to the world outside the classroom, and teachers who are engaged as coaches and facilitators rather than authority figures. 


\section{AUTHOR}

\section{LARRY A. HICKMAN}

Southern Illinois University Carbondale

lhickman[at]siu.edu 